\title{
Neutralising antibodies after streptokinase treatment for myocardial infarction: a persisting puzzle
}

\author{
K McGrath, C Hogan, D Hunt, C O’Malley, N Green, R Dauer, A Dalli
}

\begin{abstract}
Objective-To determine the development of titres of streptokinase (SK) neutralising antibodies after a single dose of SK, to establish when titres decrease to levels at which a second dose might be effective.
\end{abstract}

Design-Analyses of blood samples taken from patients at intervals after SK administration.

Setting-Australian public hospital.

Patients-104 patients with acute myocardial infarction who were treated with SK and 27 controls who were not.

Outcome measure-SK neutralising antibodies were measured once in each of the 27 controls and on 166 occasions in the 104 treated patients.

Results-Titres of SK neutralising antibodies rose after SK administration but returned to control levels by 2 years.

Conclusions-SK might be effective again as a thrombolytic agent as early as 2 years after a single dose. These results are at variance with most previously published data and the reasons for this are not clear. Data evaluating patency rates after standard doses of streptokinase in patients with increased titres of neutralising antibodies are necessary before re-exposure to streptokinase can be recommended.

(Br Heart f 1995;74:122-123)

Keywords: streptokinase; antibodies; myocardial infarction

Department of Diagnostic

Haematology, Royal

Melbourne Hospital,

Parkville, Australia

K McGrath

C Hogan

C O'Malley

R Dauer

A Dalli

Department of

Cardiology, Royal

Melbourne Hospital,

Parkville, Australia

D Hunt

N Green

Correspondence to:

Dr K McGrath, Department of Diagnostic Haematology, Royal Melbourne Hospital, Parkville, Victoria 3050, Australia.

Australia. 16 January 1995
Streptokinase (SK) improves morbidity and survival in patients with acute myocardial infarction. As a foreign bacterial protein, it provokes the formation of various antibodies, which may cause allergic phenomena, or neutralising antibodies, which may diminish or abolish the thrombolytic activity of SK. As survivors of myocardial infarction are prone to further coronary thrombosis, they may require repeat treatment with thrombolytic agents. Whether SK will be effective on a second occasion remains uncertain. Alternative thrombolytic agents are expensive and hence it is more cost effective to use repeated doses of SK.

The aim of the study was to determine the natural history of antibody titres after SK administration and to ascertain when reexposure to SK might be effective.

\section{Patients and methods}

A total of 104 patients received a standard dose of $1.5 \times 10^{6} \mathrm{U}$ of SK. No patient received steroid treatment or was known to have had previous exposure to SK. Single samples were obtained from 53 patients at 54-84 months after their SK dose. A further 51 patients who had received SK were also tested on one or more occasions between 6 and 33 months after their SK doses. Controls consisted of 27 patients from the coronary care unit who had not received SK. SK neutralisation titres were determined using the method of Hamby and Howell. ${ }^{1}$

\section{Results}

The control patients had a mean SK neutralising capacity of $0.17 \times 10^{6} \mathrm{IU}(0 \cdot 01-3 \cdot 0)$. (One patient had a neutralising capacity of $3.0 \times 10^{6}$ IU; we were unable to explain such a high titre (figure).

Titres of neutralising antibody did not differ significantly from those of the controls at 2 years after administration of SK.
Studies of neutralising antibodies at 24 or more months after administration of streptokinase

\begin{tabular}{|c|c|c|c|c|c|}
\hline Reference & Year & $\begin{array}{l}\text { Time after treatment } \\
\text { (months) }\end{array}$ & Antibody type & No of patients & $\begin{array}{l}\text { Return to } \\
\text { pretreatment } \\
\text { level at } 24 \text { months } \\
\text { or more }(\%)\end{array}$ \\
\hline Fears, et $a l^{2}$ & 1992 & 30 & $\begin{array}{l}\text { NEUT } \\
\text { IgG }\end{array}$ & $\begin{array}{l}67 \\
67\end{array}$ & \multirow{5}{*}{$\begin{array}{r}100 \\
89 \\
100 \\
50 \\
<10 \\
53 \\
70 \\
11 \\
\text { (no controls) } \\
100\end{array}$} \\
\hline Buchalter, et $a l^{6}$ & 1992 & 24 & $\begin{array}{l}\text { NEUT } \\
\text { IgG }\end{array}$ & $\begin{array}{l}8 \\
8\end{array}$ & \\
\hline $\begin{array}{l}\text { Patel, et } a l^{3} \\
\text { Lee, et } \mathrm{al}^{4}\end{array}$ & $\begin{array}{l}1993 \\
1992\end{array}$ & $\begin{array}{l}29 \\
36-54\end{array}$ & $\begin{array}{l}\text { NEUT } \\
\text { NEUT } \\
\text { IgG }\end{array}$ & $\begin{array}{r}189 \\
57 \\
57\end{array}$ & \\
\hline Elliot, et $a l^{5}$ & 1993 & 48 & NEUT & 145 & \\
\hline McGrath, et al & 1995 & $24-84$ & NEUT & 131 & \\
\hline
\end{tabular}




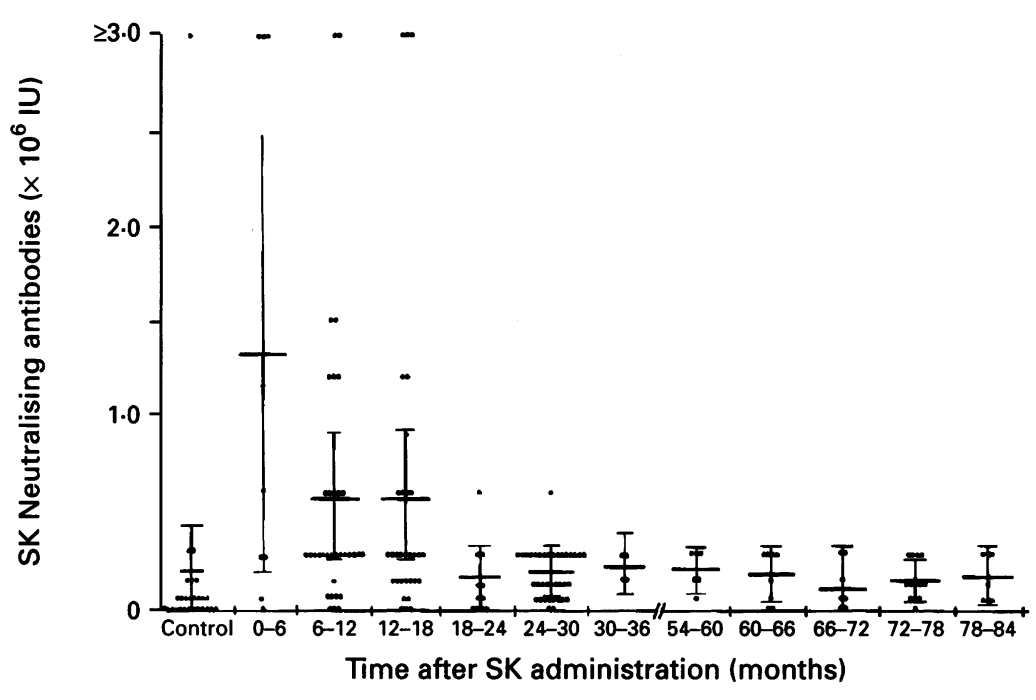

Mean (95\% confidence intervals) and individual patient levels of streptokinase (SK) antibody neutralising capacity for each interval.

\section{Discussion}

Several studies have attempted to clarify the interval after which a second dose of SK can be safely and effectively given.

Four major studies have examined levels of neutralising antibodies 2 or more years after a dose of $S K,,^{2-5}$ but the results are inconsistent (table). The method in three of the studies ${ }^{2-4}$ was similar to ours and in the others was based on release of radioactive degradation products from the clot. Three of these studies $^{3-5}$ showed increased levels of neutralising antibody at 54, 27, and 48 months respectively, while the fourth study ${ }^{2}$ demonstrated normal levels in over 90 per cent of patients by 24 months.

Three reports ${ }^{24} 6$ have looked at SK binding antibody levels. One study ${ }^{2}$ again showed normal levels in 89 per cent of patients by 18 months, while increased levels persisted to 27 and 57 months in the other studies. ${ }^{4}$

There have been three important studies ${ }^{7-9}$ of safety or efficacy of repeated doses of SK or antistreplase in patients with known increased antibody levels. Two studies ${ }^{78}$ showed good relations between raised antibody levels and hypersensitivity reactions. Of the two studies examining subsequent patency of the infarct related artery, one showed patent arteries despite increased antibody levels, ${ }^{8}$ while the other showed persistently occluded arteries. ${ }^{9}$

Thus not only does the time course of raised antibody titres remain in doubt but so also does the significance of such increases in terms of hypersensitivity reactions and thrombolytic efficacy.

1 Hawkey C, Howell M. Laboratory control of thrombolytic therapy. $\mathcal{F}$ Clin Path 1964;17:287-9.

2 Fears R, Ferres H, Glasgow E, et al. Monitoring of streptokinase resistance titre in acute myocardial infarction patients up to 30 months after giving streptokinase or anistreplase and related studies to measure specific antistreptokinase binding immunoglobulin $\mathrm{G}$ antibodies. $\mathrm{Br}$ Heart $¥$ 1992;68:167-70.

3 Patel S, Jalihal S, Dutka DP, Morris GK. Streptokinase neutralisation titres up to 866 days after intravenous streptokinase for acute myocardial infarction. Br Heart $\mathcal{F}$ 1993;70:119-21.

4 Lee HS, Cross S, Davidson R, et al. Raised levels of antistreptokinase antibody and neutralization titres from 4 days to 54 months after administration of streptokinase or anistreplase. Eur Heart $\mathcal{f}$ 1992;14:84-9.

5 Elliott JM, Cross DB, Cederholm-Williams SA, White HD. Neutralizing antibodies to streptokinase four years after intravenous thrombolytic therapy. $\mathrm{Am} ₹ \mathrm{f}$ Cardiol after intravenous

6 Buchalter MB, Suntharalingam G, Jennings I, et al. Streptokinase resistance: when might streptokinase administration be ineffective? $B r$ Heart $\mathcal{F}$ 1992;68: 449-53.

7 Lee HS, Yule S, McKenzie A, et al. Hypersensitivity reactions to streptokinase in patients with high pre-treatment antistreptokinase antibody and neutralisation titres. Eur Heart $¥ 1993 ; 14: 1640-3$.

8 White HD, Cross DB, Williams BF, Norris RM. Safety and efficacy of repeat thrombolytic treatment after acute and efficacy of repeat thrombolytic treatment after acut
myocardial infarction. $\mathrm{Br}$ Heart $\mathcal{F} 1990 ; 64: 177-81$.

9 Brugemann J, van der Meer J, Bom VJJ, et al. Anti-streptokinase antibodies inhibit fibrinolytic effects of anistreplase in acute myocardial infarction. $A m \mathcal{F}$ Cardiol 1993;72:462-4. 